\title{
The Influence of Visual Exercises on Improving the Performance of Some Skill Factors in Ping Pong
} Dr/ Haytham Gamal El Sayed Ahmed Elgamsy

\section{The Research Problem and Importance:-}

The main task of trainers today is discovering modern methods of training operation, they are physical or proficiency or planning. The visual exercises are from modern direction which can be used in training operation besides the other methods as they are very important during competition. The sport scien tists and the 8port workers seek continuously for modern methods in training to improve the sport performance and acquiring competitive advantage. They find the visual training is one of these methods which are available in the sport field. It is a repeated series of eye exercises aiming at improving the main visual functions that are necessary for excel and achievement in the sport competitions. So we find the visual training is from the important subjects that have a big importance by the researchers in the sport field generally and in ping pong especially.
As the 8ight sense has a big importance for the ping pong players.

Hitzeman

and

Beckerman (2003) emphasize that depending on the 8ight system during the sport performance is form the most usages in any activity as the vision influences the athlete ability and proficiency in performing the sport special demands. Some researchers 8tudy the relationship between the skill and the vision.

Most of the researchers' trails to determine the necessary vision for sports, and if the athletes' vision differs from others.

These trials, except they are not completed, suppose that some vision is important for performance in specific sport. The athletes' vision is different from the others' vision. Till now there are a few researches that support the hypothesis that the athletes' vision can be improvement in the visual training and that improvement in the visual potentialities will improve the sport performance. 
We need some more research trials for answering many related questions with the relationship between the vision and the sport. Brian (2007) refers to that the vision sense is the person ability to see and determine distances, and the cisual senses play an important role in the sports activity.

They produce about $80 \%$ from the sensible incomes during the sports activity, especially the activities which need a high level of the sensible realization.

The visual skill gives the athlete accurate and quick information, and it is considered the first step of the knowledge operations. It is a skill that can be improved by training. The less complete and clear data by any degree, the less degree of response, little than what expected.

The visual training requires a clear vision by the concentration ability on things severly on the pupil of the eye then the vision passages transfer the information to the brain then this information is used by the sensible and motor skills vision plays an important role in place direction, correlation accuracy and the speedy reaction, the response, and the motor and static balance.

Thus learning and perfection of the main skills in ping pong is from the most important factors that help the player achieve the winning. The play can't do any attack or defense actions without the perfection of these skills. This method has an importance that leads to positive influences of different fields. Many researchers and specialists study the influences of this method on many other sports, such as the study of Calder and Noakes (2000), Elizabeth (2003), Ashraf and Merfat (2005), Magde Ismail (2006), Nadia Elsawy and Zeinab Hathoot (2008), Huda Hassan Saber (2008), they all agree with the importance of the training of visual skills that have positive influences of developing the athletes, visual abilities.

The importance of the research increases the need for it through the big importance of the scientists who reach the positive efficiency of this method.

The researcher completes this scientific revolution what those scientists have begun. He has attempted 
this subject by research and study to be a practical guide for the trainers. He hopes that shares in developing the skills of the ping pong players as they are the real atom of making the sport champion in the world competitions.

Through the researcher's reading of the specialized scientific resources in the filed of ping pong, also throug the resource survey of the previous studies and researches through the national information Network in the Technology and scientific Research Academy. He noticed that no researcher has dealt with the subject of using the visual training and its effects on improving the level of performing some skills in ping pong.

That evokes the researcher to think of doing this research.

He tries to design a program by using the visual training and knowing its influence on the perform ace level of some ping pong skills for preparatory pupils in the sport schools.

This research aims at knowing the influence of visual training on improving the level of ping pong skills performance (serving by the front and back of racket face pushing by the front and back of racket face) for the preparatory pupils in the sport schools.

\section{* The Research Executions:- The Sample:}

The researcher has used the experimental method by using the experimental design for two groups; the first experimental and the other controlled, following the pre and post measurement a8 it is suitable for this study. The research society consists of (125) pupils, the first preparatory pupils in the sport preparatory school, East Educational Directorate, sharkia Governorate, the school year 2015-2016, by intentional way. Then the researcher chose the research sample by the hazard way, they are (40) pupils by percentage $(32 \%)$ from the research society. He got (10) pupils for doing the experimental study, so the main research sample is (30) pupils. They are divided as follows:

The experimental group (15) pupils who have the visual training, and the controlled group (15) pupils who have the traditional method of learning; 
oral explanation and doing the practical model.
The Statistic Description of the total Research Sample (Coherence):

Table (1) The Coherence of the total Research Sample in all Research Variables $N=40$

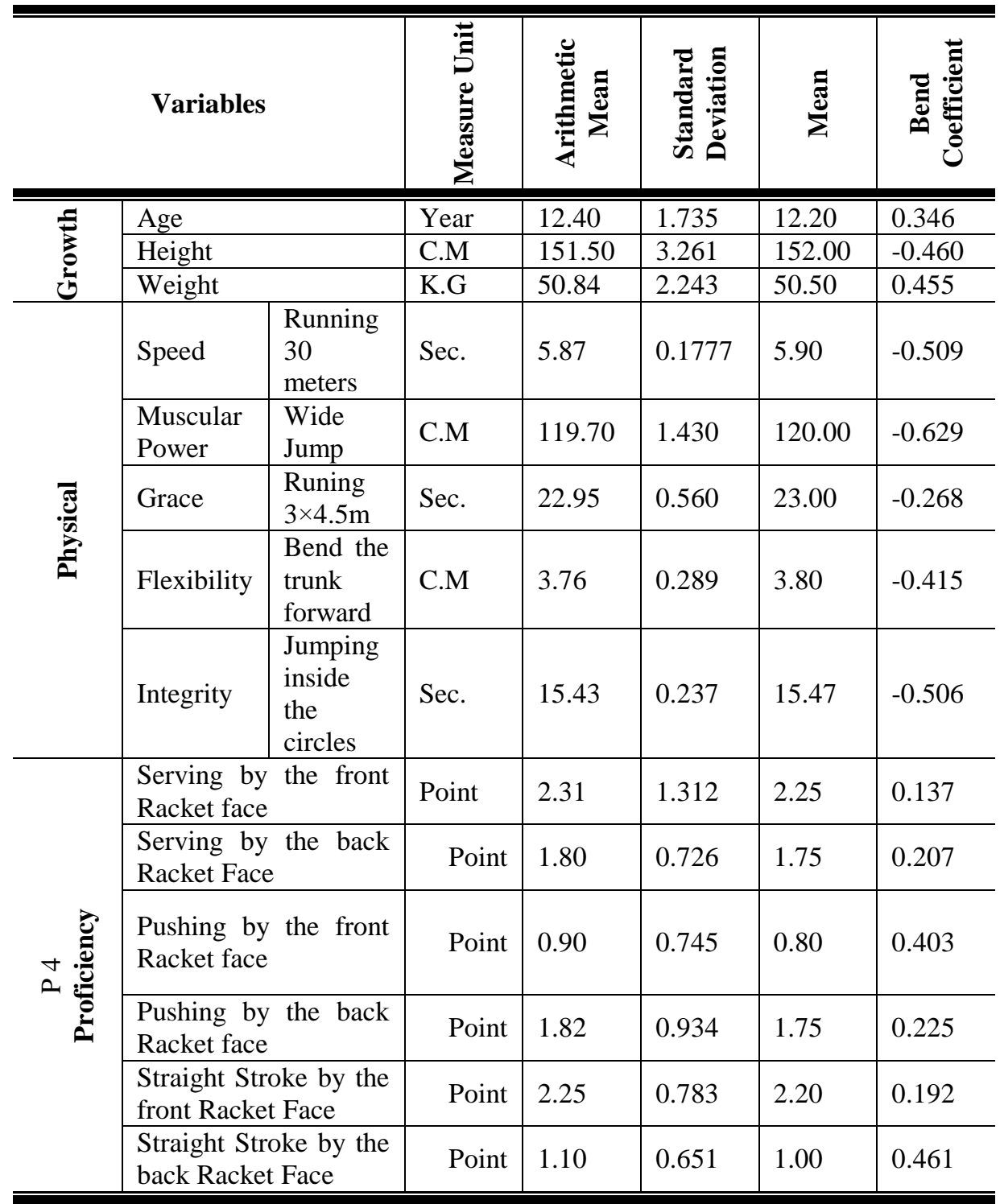


From Table (1) we notice that all standard deviations values in the growth variables and some physical and proficiency variables in ping pong, they are between $(-0.629,0.461)$, so they are between $( \pm 3)$ that refer to the homogeneity of the members of research sample in these variables.

Methods and tools of Collecting Data:-

First: The Sets and tools:

- Rastametre set for measuring height and weight.

- $\quad$ Measuring Height Tape (by centimeter) - wooden cones - collars.

- $\quad 0.1$ second - ping pong rackets - tennis tables.

They are compared by other sets to standard them for the validity of the measuring tools.

Second: The physical Tests (Appendix 3):

The researcher has determined the physical variables and the tests which measure them, through the specialized scientific resources and the precious studies, by collecting all the physical characteristics related to ping pong under research, also the physical tests related to them, and the specialist experts show them to determine the most important physical characteristics 8uitable for this research, also the physical tests which measure them (Appendix 2). They are revised by ten experts in Methodology and ping pong (Appendix 2). The researcher chose $70 \%$ or more for the most physical variables then he accepted the following tests:

Running 30 metres from the high beginning for measuring the transmitted speed, and the wide jump from stediness for measuring the legs muscular power, zigzag running by power method $3 \times 4.5 \mathrm{~m}$ for measuring the grace, bending the trunk forward from standing for measuring the flexibility, the numbered speed circles for measuring the coherence.

\section{Third: The Proficiency Tests} (Appendix 5)

Through looking in many specialized scientific resources that have been done in ping pong field, and by assistance of some test Battery Units for the basic skills in ping pong, as the study of

$$
\text { (P. 5) Mohamed }
$$

Saad El Deen El Sayed (2002), Magdy Ahmed Shawky (2002) Fathy Ahmed El Saqaf (2010).

The researcher has asked the opinion of the experts (Appendix 1) for counting the 
most important tests that measure these skills. He chose the percentage $70 \%$ or more for the most important proficiency variables. $\mathrm{He}$ accepted the following proficiency tests:

Serving by the front racket face, and serving by the back rracket face.

- Pushing by the front racket face, and pushing by the back racket face.

- $\quad$ Straight strorke by the front racket face, and the straight stroke by the back racket face.

\section{The Experimental Study:}

The researcher has done an experimental study on (10) pupils from the research society; out the main research sample, in the period from $11 / 10$ to $15 / 10 / 2015$ to emphasize the validity of the used place, and tools and sets for performing the measurements and tests, and know the troubles that may face the researcher during the measurements and tests, and train the assistants on doing the measurements and test, and organize the sample members for doing the measurements and tests in less time and effort, and emphasize the validity of the register from, and know the scientific factors (reliability - Steadiness) for tests under research.

The Suggested Educational Program (Appendix 8):

The researcher took the opinion of the experts (Appendix 1) around determine the most important visual exercises that influence some proficiency variables in ping pong under research, then he prepared the suggested educational program.

\section{Contents of the Educational Program:}

The suggest educational program contains visual exercises that help in improving the performance level of some pingpong skills under research for the first grade preparatory pupils by what agree with the variables nature under the research.

\section{Time of the Educational program:}

The program contains eight weeks for 16 Units two units a week, each unit 45 minutes.

\section{Fifth: The Training Preparation Steps:}

The researcher has revised many previous resources and studies that relate to educational program in ping pong, then he collected 
many of correlated exercises with vision, then sort them to exercises for improving (the head position - the vision angle - the motor and static vision accuracy the vision field - the visual realization - the visual chasing) then they have supervised by the experts. They are (45) exercises in their first conception (Appendix 6).

The researcher put these exercises in the figure of a program that suits the research objectives. He took away the exercises that the experts do not agree with. The final agreeable exercises are (40) (Appendix 7).

The pre-measurements:

After being used the scientific factors (steadiness reliability) of the proficiency tests in ping pong under research through the experimental study by doing the pre-measurements on the experimental and controlled research sample during 18 , 19/10/2015.

Measuring the proficiency performance level:

The researcher has measured the proficiency performance level in ping pong under research by a committee of three refrees (Appendix 1). The Main Study:

The researcher has applied the suggested educational program by using the visual training on the experimental group while applying the traditional method (oral explanation - giving the practical model) on the controlled group in the period from $25 / 10 / 2015$ to $17 / 12 / 2015$ for eight weeks. They contain (16) educational unit, two units a week. The researcher has followed the following steps:

- The Post Measurements:

He hasdone the post measurements after the eighth week on the two groups; the experimental and the controlled on 20, 21/12/2015. they contain the same premeasurements and by the same conditions.

- The Statistics Treatment:

He has used the suitable statistics treatment for the mature of the research by using (SPSS) program for performing the mathematical and statistic research Operations.

Discussing the Results: 
Table (2)

The Statistic Differences Denotations Between The Averages of Pre and Post Measurements for the Experimental Group in Some ping pong Skills Under Research $\mathrm{N}=15$

\begin{tabular}{|c|c|c|c|c|c|c|c|}
\hline \multirow{2}{*}{\multicolumn{2}{|c|}{ Variables }} & \multirow{2}{*}{$\begin{array}{l}\text { Measure } \\
\text { Unit }\end{array}$} & \multicolumn{2}{|c|}{$\begin{array}{l}\text { Pre- } \\
\text { Measurement }\end{array}$} & \multicolumn{2}{|c|}{$\begin{array}{l}\text { Post } \\
\text { measurement }\end{array}$} & \multirow{2}{*}{$\begin{array}{l}\text { T } \\
\text { Value }\end{array}$} \\
\hline & & & $\mathbf{S}_{1}$ & $\pm M^{1}$ & $\mathbf{S}_{2}$ & $\pm M^{2}$ & \\
\hline \multirow{6}{*}{ 递 } & $\begin{array}{l}\text { Serving by } \\
\text { the front } \\
\text { racket face }\end{array}$ & Point & 2.35 & 1.187 & 4.50 & 0.624 & 5.999 \\
\hline & $\begin{array}{l}\text { Serving by } \\
\text { the back } \\
\text { racket face }\end{array}$ & Point & 1.75 & 0.719 & 3.25 & 0.341 & 7.053 \\
\hline & $\begin{array}{l}\text { Pushing by } \\
\text { the front } \\
\text { racket face }\end{array}$ & Point & 0.78 & 0.747 & 3.34 & 0.489 & 6.538 \\
\hline & $\begin{array}{l}\text { Pushing by } \\
\text { the back } \\
\text { racket face }\end{array}$ & Point & 1.79 & 0.926 & 4.20 & 0.657 & 7.942 \\
\hline & $\begin{array}{l}\text { Straight } \\
\text { Stroke by } \\
\text { front racket } \\
\text { face }\end{array}$ & Point & 2.20 & 0.762 & 3.75 & 0.563 & 6.121 \\
\hline & $\begin{array}{l}\text { Straight } \\
\text { Stroke by } \\
\text { back racket } \\
\text { face }\end{array}$ & Point & 1.00 & 0.625 & 2.25 & 0.351 & 6.525 \\
\hline
\end{tabular}

"T" tabled value in the level $0.05=2.145$

from table (2) we notice there are statistic denoting differences in the level 0.05 between the averages of pre and post measurements for the experimental group in all proficiency variables in ping pong (serving by the front racket face - serving by the back reacket face - pushing by the front racket face - pushing by the back racket face straight stroke by front racket face - straight stroke by back racket face) for the side of the post measurement. The calculated "T" value is bigger than tabled "T" value in the

Assiut Journal For Sport Science Arts 
level 0.05 . the researcher relates these differences to the suggested educational program by using the visual training which contains some potentialities that lead to develop and improve the visual abilities that have their role and positive influence in the level of ping pong skills performance level under research so the highest standard has been achieved. This explanation is for the positively of visual abilities in developing the performance level that requires firstly developing it as it is the basis of variables development. The visual exercises help in under standing the learning stages that leads to learn ping pong skills under research. Besides using the visual abilities in learning attracts the students, attention and not feeling bored, also in creases their interest and enthusiasm, and their positive ness, thus what they have learned keeps its influence.

Abernethy and wood (2001) agree with these results, that there are denoting statistic differences between the pre and post measurements in the proficiency variables under research of the experimental group for the post measurements. We also notice that ping pong skills performance requires awakeness and visual concentration. The pupil since standing for performing the serving trial concentrates and does the visual expectation. When he does the straight stroke by the front and back racket face, the visual concentration and accuracy increase through visual suggested training of eyes. Abernethy and wood (2001), Merfat Mohamed Rashad (2005) agree with these results about the importance of the visual training that influence the player visual abilities. Also Hamed Hussien, Mohamed Essam and Mohamed Abd Elsalam (2008) agree with these results that the visual training improves the digital level of pole vault.

Donal and Caroline (2005) add that some skills performance in many sport activities are hard to be supervised by the eye. The video Analysis shows that Case. So the term of "visual expectation" has appeared.

For example: It is hard for the ping pong player to see the moving line of the ball in 
the period $0.05-20 \mathrm{sec}$. before it will be hit by the racket. Zieman and others refer to the visual training in sport field is a very small area in the performance system, but it is very important, especially in the last decades.

The researcher relates the development in the visual accuracy; static and motor, to

\section{Table (3)}

The statistics Difference Denotations between the Averages of pre and post Measurements for the controlled Group in some proficiency variables in ping pong under $\operatorname{Research}(N=15)$

\begin{tabular}{|c|c|c|c|c|c|c|c|}
\hline \multirow{2}{*}{\multicolumn{2}{|c|}{ Variables }} & \multirow{3}{*}{$\begin{array}{c}\begin{array}{c}\text { Measure } \\
\text { Unit }\end{array} \\
\text { Point }\end{array}$} & \multicolumn{2}{|c|}{$\begin{array}{c}\text { Pre- } \\
\text { Measurement }\end{array}$} & \multicolumn{2}{|c|}{$\begin{array}{c}\text { Post } \\
\text { measurement }\end{array}$} & \multirow{3}{*}{$\begin{array}{c}\begin{array}{c}\mathbf{T} \\
\text { Value }\end{array} \\
2.484\end{array}$} \\
\hline & & & \multirow{2}{*}{$\begin{array}{l}\mathbf{S}_{\mathbf{1}} \\
2.40\end{array}$} & \multirow{2}{*}{$\frac{ \pm \mathbf{M}^{\mathbf{1}}}{1.194}$} & \multirow{2}{*}{$\frac{\mathbf{S}_{\mathbf{2}}}{3.25}$} & \multirow{2}{*}{$\begin{array}{l} \pm \mathbf{M}^{2} \\
0.462\end{array}$} & \\
\hline \multirow{6}{*}{ 导 } & $\begin{array}{l}\text { Serving by } \\
\text { the front } \\
\text { racket face }\end{array}$ & & & & & & \\
\hline & $\begin{array}{l}\text { Serving by } \\
\text { the back } \\
\text { racket face }\end{array}$ & Point & 1.70 & 0.738 & 2.30 & 0.367 & 2.724 \\
\hline & $\begin{array}{l}\text { Pushing by } \\
\text { the front } \\
\text { racket face }\end{array}$ & Point & 0.75 & 0.742 & 0.30 & 0.538 & 2.245 \\
\hline & $\begin{array}{l}\text { Pushing by } \\
\text { the back } \\
\text { racket face }\end{array}$ & Point & 1.86 & 0.945 & 2.64 & 0.765 & 2.400 \\
\hline & $\begin{array}{l}\text { Straight } \\
\text { Stroke by } \\
\text { front racket } \\
\text { face }\end{array}$ & Point & 2.30 & 0.816 & 3.00 & 0.638 & 2.529 \\
\hline & $\begin{array}{l}\text { Straight } \\
\text { Stroke by } \\
\text { back racket } \\
\text { face }\end{array}$ & Point & 1.15 & 0.719 & 1.60 & 0.249 & 2.213 \\
\hline
\end{tabular}

"T" tabled value in the level $0.05=2.145$

Assiut Journal For Sport Science Arts 
From table (3) we notice that there are denoting statistic differences in the level 0.05 between the measurements averages for the controlled group in some ping pong skills under research for the side of the post measurement. The researcher relates the little improvement between the pre and post measurements to the pupils' engagement; the experimental and the controlled group, in learning ping pong skills. They imitate each other in doing these skills that enables them to improve some visual abilities through watching the controlled group to the experimental group. The researcher also relates these positive results for the controlled group in all ping pong skills under research to the usage of the traditional method which model of the basic skills then introduces a group of gradual exercises from easy to difficult, from simple to complex, and practice and repetition the skill performance by pupils and the teacher supervises and corrects the mistakes.

So they can learn correctly according to the skill technical proficiency, thus they influence positively the proficiency performance level. Todorov and others (1997), Fayez Murad and Al Ameen Abd El Hafeez (2003), Fekry Hassan Rayyan (2004) agree with this result, the learning method by order is form the direct methods for the speedy reach information and acquire skills from teacher to pupil, the teacher feels privillge and control the educational situation, he can adapt the control the educational situation, he can adapt the circled environment circumstances during learning. Mahmoud Abd El Haleem Abd El kareem (2006) refers to that the teacher in this method is making the decisions and the main controller in the educational process, that can emphasize the learner success and determine his direction during the educational process. Kamal Abd El Hameed Zaytoon (2004) adds that the old traditional method in teaching sees the learner as a mind to pour information, $\mathrm{He}$ is a mere receiver.

But the modern method in learning (self learning) sees the learner as a living creature, it aims at his progress and growth, not keeping 
information, but building the learner of knowledge according to his treatment to it

Table (4)

The Denotation of the Statistic Differences between the Averages of the two post measurements for the two group; the experimental and the controlled, in some ping pong skills under Research

$\mathrm{N}_{1}=\mathrm{N}_{2}=15$

\begin{tabular}{|c|c|c|c|c|c|c|c|}
\hline \multirow{2}{*}{\multicolumn{2}{|c|}{ Variables }} & \multirow{3}{*}{$\begin{array}{l}\begin{array}{l}\text { Measure } \\
\text { Unit }\end{array} \\
\text { Point }\end{array}$} & \multirow{2}{*}{\multicolumn{2}{|c|}{$\begin{array}{l}\text { Pre- } \\
\text { Measurement }\end{array}$}} & \multicolumn{2}{|c|}{$\begin{array}{l}\text { Post } \\
\text { measurement }\end{array}$} & \multirow{2}{*}{$\begin{array}{l}\text { T } \\
\text { Value } \\
8.670\end{array}$} \\
\hline & & & & & & & \\
\hline \multirow{6}{*}{ 递 } & $\begin{array}{l}\text { Serving by } \\
\text { the front } \\
\text { racket face }\end{array}$ & & $\begin{array}{l}\mathbf{S}_{\mathbf{1}} \\
4.50\end{array}$ & $\begin{array}{l} \pm \mathbf{M}^{1} \\
0.624\end{array}$ & \begin{tabular}{|l}
$\mathbf{S}_{\mathbf{2}}$ \\
3.25
\end{tabular} & $\begin{array}{l} \pm \mathbf{M}^{2} \\
0.462\end{array}$ & \\
\hline & $\begin{array}{l}\text { Serving by } \\
\text { the back } \\
\text { racket face }\end{array}$ & Point & 3.25 & 0.341 & 2.30 & 0.367 & 10.212 \\
\hline & $\begin{array}{l}\text { Pushing by } \\
\text { the front } \\
\text { racket face }\end{array}$ & Point & 2.34 & 0.489 & 1.30 & 0.538 & 7.703 \\
\hline & $\begin{array}{l}\text { Pushing by } \\
\text { the back } \\
\text { racket face }\end{array}$ & Point & 4.20 & 0.657 & 2.64 & 0.765 & 8.331 \\
\hline & $\begin{array}{l}\text { Straight } \\
\text { Stroke by } \\
\text { front } \\
\text { racket face }\end{array}$ & Point & 3.75 & 0.563 & 3.00 & 0.638 & 4.747 \\
\hline & $\begin{array}{l}\text { Straight } \\
\text { Stroke by } \\
\text { back } \\
\text { racket face }\end{array}$ & Point & 2.25 & 0.351 & 1.60 & 0.249 & 8.134 \\
\hline
\end{tabular}

"T" tabled value in the level $0.05=2.045$

From table (4) we notice that there are denoting statistic difference in the level 0.05 between the averages of the post measurements for the two groups; the experimental and the controlled in all physical

variables and ping pong skills under research for the side of the experimental group - the researcher relates this result to the visual exercises that need big coherence between the eye and the hand; and the legs 
motions in the suitable places for the performance of ping pong skills. These visual exercises help with improving and developing the visual abilities for the pupils of the experimental group which share in improving the proficiency performance level. The suggested program has effectiveness by using the visual exercises that give the pupil the true motor conception of the skills, especially the speedy ones.

Also it enables the pupils to recognize the successive stages of the skill performance through the clear vision, while the traditional method (oral explanation and doing the practical model) does not enable some pupils to follow up the explanation then they find difficulty in understanding.

Also there are some pupils who can't see the skill model correctly from different angles, so they can't know the technical aspects of doing the skill in the right way. In some speedy motor skills, some pupils can't follow up the motor performance steps of the skill, that can influence their learning of the skill correctly. Ali da Anelia (2003), Ashraf Katab and Merfat Rashad (2005), Gehan Mohamed Fouad and Eman Abdullah (2005), Hamed Hussien and Mohamed Essa and Mahmoud Abd Elsalam (2006), Mahmoud Abd El mhsen Abd El Rahman (2008) agree with these results that the visual training program leads to improve the proficiency performance level for the experimental group under research

Table (5)

The Percentages of the post Measurement Improvement than the pre- measurement for the experimental and controlled groups in some ping pong skills under Research

\begin{tabular}{|c|c|c|c|c|c|c|c|}
\hline \multirow[b]{2}{*}{ Variables } & \multicolumn{3}{|c|}{ Experimental Group } & \multicolumn{3}{|c|}{ Controlled Group } & \multirow[b]{2}{*}{$\begin{array}{l}\text { Change } \\
\text { Rate }\end{array}$} \\
\hline & Pre & Post & $\begin{array}{l}\text { Improve } \\
\text { Per. \% }\end{array}$ & Pre & Post & $\begin{array}{l}\text { Improve } \\
\text { Per. } \%\end{array}$ & \\
\hline $\begin{array}{l}\text { Serving by } \\
\text { the racket } \\
\text { face }\end{array}$ & 2.35 & 4.50 & 91.49 & 2.40 & 3.25 & 35.42 & 56.07 \\
\hline $\begin{array}{l}\text { Serving by } \\
\text { the back } \\
\text { racket face }\end{array}$ & 1.75 & 2.25 & 85.71 & 1.70 & 2.30 & 33.29 & 50.42 \\
\hline
\end{tabular}

Follow Table (5)

Assiut Journal For Sport Science Arts 
The Percentages of the post Measurement Improvement than the pre- measurement for the experimental and controlled groups in some ping pong skills under Research

\begin{tabular}{|c|c|c|c|c|c|c|c|}
\hline \multirow[b]{2}{*}{ Variables } & \multicolumn{3}{|c|}{ Experimental Group } & \multicolumn{3}{|c|}{ Controlled Group } & \multirow{2}{*}{$\begin{array}{l}\text { Change } \\
\text { Rate }\end{array}$} \\
\hline & Pre & Post & $\begin{array}{l}\text { Improve } \\
\text { Per. \% }\end{array}$ & Pre & Post & $\begin{array}{l}\text { Improve } \\
\text { Per. \% }\end{array}$ & \\
\hline $\begin{array}{l}\text { Pushing by } \\
\text { the front } \\
\text { racket face }\end{array}$ & 0.78 & 2.34 & 200.0 & 0.75 & 1.30 & 73.33 & 162.67 \\
\hline $\begin{array}{l}\text { Pushing by } \\
\text { the back } \\
\text { racket face }\end{array}$ & 1.79 & 4.20 & 134.64 & 1.86 & 2.64 & 41.94 & 92.70 \\
\hline $\begin{array}{l}\text { Straight } \\
\text { Stroke by } \\
\text { front racket } \\
\text { face }\end{array}$ & 2.20 & 3.75 & 70.46 & 2.30 & 3.00 & 30.44 & 40.02 \\
\hline $\begin{array}{l}\text { Straight } \\
\text { Stroke by } \\
\text { back racket } \\
\text { face }\end{array}$ & 1.00 & 2.25 & 125.0 & 1.15 & 1.60 & 39.13 & 85.87 \\
\hline
\end{tabular}

From Table (5) we notice there are improvement percentages for the post measurement than the premeasurement for the experimental and the controlled groups in all basic skills in ping pong under research. The experimental group gets higher rates than the controlled group. The best improvement percentages in proficiency variables is in pushing the ball by the front racket face by percentage (200\%). The least improvement percentages in straight stroke by the front racket face by percentage
(70.46\%) for the experimental group. But the controlled group has the best improvement percentages in proficiency variables in pushing the ball by the front racket face by percentage $(73.33 \%)$, The least improvement percentages in straight stroke by the front tracket face by $(30.44 \%)$. The researcher relates the excel of the experimental group than the controlled group in the improvement of the post measurements than the premeasurements to the influence of the suggested visual training.

*Results and Recommendations:- 
First: The Results:

The visual training influences the improvement of the ping pong skills performance (serving by the front and the back racket face pushing by the front and the back racket face).

The influence of the orders method on the controlled group in ping pong skills performance under research for pupils is very little; compared by the influence of the visual training on the experimental group.

There are statistic differences between the two post measurements for the experimental and the controlled group in ping pong skills performance under research for the side of the experimental group.

The experimental group has higher improvement percentages in all ping pong skills under research than the controlled group.

Second: Recommendations:-

- pay attention to the visual training as it has an effective influence on developing the ping pong skills performance level under research.

Entering the visual exercises under research to the programs of ping pong skills learning in the sport school.

- Jive interest of the visual exercises in the sport field generally, and especially in the ping pong skills.

- Do more studies of the visual exercises on the other skills of ping pong.

\section{References:}

1- Eleen wadeea Farag and Salwa Ezz Eldeen (2013) the Resource in ping pong, teaching and training, second Edition, ElMaraf Ins, Alexandria.

2- Gehan Mohamed Fouad and Eman Abd allah (2005) the Effectiveness of visual training on same proficiency skills and visual abilities in volleyball, magazine of comprehensive Education Researches, first volume, Faculty of physical Education for females, Zagazig university.

\section{3- Hamed Hussien and}

Mahmoud Esaa and Mahmoud Abd Elsalam (2008): The Influence of visual training on some visual abilities and the digital and technical performance level in pole valult, published Research in the scientific conference, Serbia. 
4- Sahar Abd Allah

Salama (2015): the Influence of using the visual Exercises on improving the long jump for the Athletics Beginners, unpublished Master Message, Faculty of physical Education for females, Zagazig University.

5- $\quad$ Fayez Murad and El Ameen Abd ElHaffez (2003): Practical Education Guide and Teachers Preparation, Dar El Wafaa for Publishing. Alexandria.

6- Fathy Ahmed El Saqaf (2010): Ping pong Sport, Skills - Growth Stages Choosing - Coach, Horus international Institution for publishing. Cairo.

7-

$$
\text { P. } 13 \text { Fekry }
$$

Hassan Rayyan (2004):

Teaching, Objectives - Basis Evaluation - Applications, Alam El Kotob, Cairo.

8- Kamal Abd El
Hameed Zaytoon (2004): Education technology in the communication and Information Age, Alam El Ketab, Cairo.

9- Magda Ismail (2006): The Effectivenss of Visual Training Program on some visual skills and recognition skills and their relation with some skills performance level of control and supremacy for gymnastics beginners, published Research in Comprehensive Education Research Magazine, First Volume, Faculty of Physical Education for females, Zagazig University.

\section{0- Magdy}

Ahmed

Shawky (2002): Theoritical Basis of ping pong and practical Applications, Arabic Publishing Centre, Zagazig.

11- Mohamed Ahmed Abd Allah (2007): the Scientific basis in ping pong and Measuring Methods, Ayaat Publishing and computer Centre, Zagazig.

12- Mohamed Hassan Alawy and Mohamed Nasr El Deen Raswan (2001): Sport performance test, Second Edition, Dar El Fekr Al Araby, Cairo.

\section{3- Mohamed Saad El} Deen El Sayed (2002): Series of Sport Curriculums, Ping Pong Curriculum, Publishing Adminstration of Information and Document centre, Preparation of Leaders Sector, the High Council of Sport and Youth, Giza.

14- Mohamed Soby Hassanned (2001): Evaluation and Measurement in the physical Education, first part, Assiut Journal For Sport Science Arts 
fourth Edition, Dar El Feker Al Araby, Cairo.

15- Mohmoud Abd El Haleem Abd El Kareem (2006): Dynamics of physical Education Teaching, Book Publishing Centre Cairo.

16- Mohamoud Abd El Mohsen Abd El Rahman (2008): The influence of visual training on the free defense player in volleyball, unpublished PHD Message, faculty of physical Education, Minia University.

\section{7- Merval Mohamed}

Rashad (2005): the

Effectiveness of the visual training on Balance and some visual abilities in fencing, Comperhensive Education Research Magazine, Second Volume, second Edition, Faculty of physical Education for females, Zagazig university.

18- Nadia Hassan El Sawy and Zeinab Ali Hathoot (2008): the Effectiveness of visual training on the recognition skills and visual abilities and improving the proficiency attack level in Handball, the International Scientific conference, faculty of physical education for females, Zagazig University. 19- Huda Hassan Saber (2008): The Influence of using the visual training on improvement the accuracy of scoring points and paying attention for cometa female players, unpublished master message, faculty of physical education for females, Zagazig University.

20- Abernethy \& Wood (2001): Do generalized vault training programmes for sport really work? an experimental invest taxation, sports sic, mat.

21- Alida, Anelia (2003):

The visual skills of professional and amateur rugby players, diss of $\mathrm{m}$. Sc, faculty of science, rand Africans university.

22- Ashraf K., \& Merfat R., (2005): A specific visual skills training programmer improves fencing performance level, visual variables and static balance, 10lh annual congress of the European college of sport science Belgrade,

23-

Barry Seller, (2004):

Positive effect of visual skills development

program, Assiut Journal For Sport Science Arts 
optometry and visual science, Vol. 5, 277-280.

24- Brian, R., (2007):

Visual skill and pole vaulting national pole-vault chair for Canada.

25- Calder \& Noakes (2000): A specific visual skills training programme unproven filed hockey performance, international congress on sport science 13, SeptemberBrisbane, Australia.

26- Donal, I.J., Caroline, (2005): Inspection of time and high speed ball games, perception and motor learning journal, Vol. 18, 789-792.

27- Elizabeth, Bressa (2003): Effects of visual skills training vision coaching and sport vision dynamics on the performance of sport skill, African journal for physical, health, recreation and dance.

28- Hitzeman SA.,

Beckerman SA., (2003): The demands on the visual system during athletic, London, 3(1): 69-145.

29- Isabel Walker

(2001): Why visual training programmes for sport don't work, sport Sci., Mar 19 (3) p22-203.

30- Todorov, Shadmehr, Bizzi (1997): Augmented feedback presented in A virtual environment accelerates learning of A difficult motor task, Journal of Motor Behavior (Washington, D.C.), Vol. 29 (2), June, p. 147- 158.

31- Zieman, AN., Hascelik, Z., Basgoze, Tucker, K., Narman, S., Ozker (2003): The effects of physical training on physical fitness tests, auditory and visual reaction times for volleyball players, journal of sport medicine and physical fitness, Vol. 29, 234- 239. 